\title{
The Role of Women Farmers in Lowland Rice Production in Parigi Moutong Regency of Central Sulawesi
}

\author{
RUSTAM ABDUL RAUF ${ }^{1 *}$, MUHAMMAD DWI SAPUTRA $^{1}$, EFFENDY $^{1}$, MUHARDI $^{2}$ \\ ${ }^{1}$ Department of Agriculture Economics, Agriculture Faculty of Tadulako University, Palu, \\ INDONESIA \\ ${ }^{2}$ Department of Agroecotechnology, Agriculture Faculty of Tadulako University, Palu, INDONESIA \\ * Corresponding Author Email: rustamabdulrauf@ yahoo.com
}

\begin{abstract}
Women farmers could contribute to reducing poverty in rural areas; for example, empowering women farmers could improve their ability to produce lowland rice. This study aimed to analyze the socioeconomic factors that affected the role of women farmers in the production of lowland rice; also, to analyze the effect and the role of women farmers on lowland rice yields. Data collection included a questionnaire and involved 168 respondents, who were taken by the census. Data analysis used multiple and logit regression of Cobb-Douglas models. The results showed that education and farming income had a positive and significant effect on the role of women farmers in lowland rice production. The yield of lowland rice was affected by land area, urea fertilizer, SP-36 fertilizer, labor, and the role of women farmers.
\end{abstract}

Key-Words: - women farmers, education, farming income, lowland rice production

Received: October 9, 2020. Revised: March 23, 2021. Accepted: April 2, 2021. Published: April 9, 2021.

\section{Introduction}

The main source of income of people in rural areas of Indonesia is still dependent on the agricultural sector, suggesting that most of the household economy depended on the same sector [1]. One of the agricultural commodities expected to be able to positively increase the farmers' household economy in rural areas was lowland rice-a commodity considered to be the most ably managed by farmers because apart from being a staple food, it is also a strategic commodity of high economic value [2]. Even nationally, this commodity was expected to realize the government's desire to be self-sufficient in rice — as happened once in 1984.

There are several factors that could create selfsufficiency through rice production; in particular, labor resources, consisting of both men and women. The role of women in this sector is significant. In lowland rice farming, the division of work between men and women is very clearly seen: men do the 'muscle' work while women focus on activities that requiring accuracy and neatness - or, those which take a lot of time [3].

The phenomenon of women in the agricultural sector is, for the community, nothing new. History shows that the origin of agriculture began with the division of work between men and women; the men did the work of hunting and gathering while women's work centered around the home and caregiving. The more developed the community, the more agricultural success was consistently carried out by both men and women. Agricultural development could not be realized without the active role of farmers and their families-especially women farmers [4].

According to the International Cooperative Alliance [5], Worldbank [6] and Valdivia [7], working in a collective system could have the potential to empower women in open markets in a way that they could not reach as individual producers. As a result, women could contribute a lot to households and reduce poverty in rural areas [8].

The empowerment of women could increase their ability to access and get benefits as stakeholders [9]. Several studies [10-13] have shown that women can be important actors in production and development of the product. In Parigi Moutong Regency, women effectively took part in managing lowland rice farming; in addition, they were responsible for household caregiver tasks.

This study aims to analyze the socioeconomic factors that affect the role of women farmers in lowland rice production. It also analyzes the effect of input and the role of women farmers on rice yields. The results of this study could provide recommendations on strategies to increase lowland rice production. 


\section{Literature Review}

\subsection{Concept of Gender}

The term gender was first introduced in America in the 1960s as a result of the radical, conservative, secular, and religious struggles to voice women's existence, which thus gave birth to gender awareness [14]. Gender is a personality characteristic, as people are influenced by their gender roles and grouped into four classifications, namely: masculine, feminine, androgynous, and unclassified [15]. Gender is therefore a characteristic of the socially determined roles and responsibilities assigned to women and men [16]. The concept results from social construction, which is constantly changing and can be transferred and exchanged according to time, place, and local culture from one gender to another. The concept of gender also includes the characteristics or traits of men and women that individual families and/or societies create in accordance to their culture and religious interpretations [17]. For example, in general, cooking, caring for children, and washing are mentioned only as women's work. This view is a social creation, resulting from a certain culture, even though the work can also be exchanged with or completed by men. However, this view may differ from one culture to another. These characteristics or traits distinguish men and women, which is known as gender differentiation. This distinction often results in men and women having different social roles. Each role is learned and changes over time and place. Social roles, or gender roles, affect the pattern of power relations between women and men, which are often referred to as gender relations [18].

Biological differences are believed to affect instinctive roles. The class struggle between men and women has never achieved satisfactory results because humans need partnership and cooperation structurally and functionally. Both women and men have different natures according to their respective functions [19], and labor is consequently divided in social and family life. The husband and wife must agree on who is the head of the family and who does the housework to achieve their goals. A family is a social unit that provides different roles, and the husband and wife thus complement and help each other. Indeed, the family's role is increasingly important in modern society, especially for caring for and educating children. Harmony in life can only be achieved if there is a harmonious division of roles and tasks between women and men, and this division starts early through education and childcare.

Gender injustice and discrimination are conditions of inequality, resulting from the social structure system that victimizes both women and men
$[20,21]$. Gender injustice occurs because of belief and justification that is implanted throughout human civilization in various forms. This injustice is mostly experienced by women, but also affects men. Gender injustice manifests due to gender discrimination, including (1) Marginalization: a process, attitude, social behavior, or state policy that results in marginalization/impoverishment of women or men; (2) Subordination: a belief that one gender is considered more important than the other, so one gender feels their voice is not heard, and even tends to be exploited; (3) Stereotype View: labeling, which is often negative towards one particular gender; (4) Violence: an attack on a person's physical or psychological mental integrity, including nonphysical acts such as sexual harassment, threats, and coercion that are emotionally and mentally disturbing, as well as physical attacks such as rape, beatings, and torture; and (5) Multiple Burden: the role and responsibility of a person in carrying out various types of daily activities.

\subsection{Gender equality}

Gender has many implications in human life, but most influentially, it becomes the foundation of interpersonal inequality [22]. Equality for everyone has different meanings, but universal equality refers to the right of every individual to think freely, find meaning, and determine their own choices and goals in life. There are several theories that explain gender equality and justice [23-25], namely: nurture theory, nature theory, and the balance of the two theories, known as equilibrium theory.

Nurture theory states that the differences between men and women are formed through socio-cultural construction, resulting in different roles and tasks. These differences cause women to be left behind and neglect their roles and contributions within their family and community, as well as their national and state life. Indeed, social construction places women and men in different classes. Men are identified with the bourgeoisie, while women are proletarians. In the process of development, many women are aware of the weaknesses of nurture theory, and thus turn to the nature theory. The nurture approach arguably does not create peace and harmony in family and community life.

Nature theory claims that the distinction between men and women is natural, so it must be accepted. Biological differences provide indications and implications that the two genders have different roles and duties. Some roles and tasks that can be exchanged, but others cannot, because they are naturally different. 
In addition to these two theories, equilibrium theory offers a compromise that emphasizes the concept of partnership and harmony in the relationship between women and men. This view does not cause conflict between women and men, because they must work together in partnership and harmony within the family, society, nation, and state.

Gender is a socio-cultural variable in which a set of assumptions determine how men and women behave [26]. A portion of the burden (biological physical strength) cannot be used as an indicator of equality, even though women have the right to choose tough work. Gender equality therefore cannot be defined narrowly, but men should not be able to become women, and women should not be able to become men, because equality does not shape the individual into an artificial figure.

The culture of today's society is created by men, and men are often the decision-makers [26]. The history of differentiation between men and women occurs through socialization, socio-cultural construction, religion, and even through state power. Through a long process, gender gradually appears to arise from God's nature or an irreversible biological requirement [27]. The gendered labor division places women in the domestic sector, caring for children and serving their husbands. Meanwhile, men are placed in the public sector to earn a living for the family. This trend is then internalized continuously from generation to generation. Consequently, these social expectations impact opportunities for women to participate in activities outside their traditional sphere [24]. Of course, participating in the public sphere does not necessarily give women a share of the same workload, but rather provides them with the same opportunities to do what they want in terms of education, careers, or politics. Any woman's profession should therefore be respected, whether she is a housewife or a working woman. People should not make a one-sided assessment of the choices women make, or determine which figure is the ideal woman. Instead, opportunities should be provided and individual choices should be respected.

Gender equality is not providing men and women with the exact same rights and obligations without any exceptions. Instead, it refers to optimizing the role function in these rights and obligations according to each gender, without closing the possibility of a role exchange. Indeed, the concept of gender is not absolute, so many negotiations can be undertaken to achieve the right roles [28]. Women and men differ, but they have an equal position, and no one is higher or lower, because their relationship is complementary to each another. Each gender can play an optimal role in their own sphere without having to be something other than themselves, because there is a fundamental line that is too difficult for both of them to cross.

It is ironic to consider that equality will only be achieved if men and women obtain the same roles and activities, because this involves attracting women to a place where they must be willing to bear the heavy burdens men usually bare [29]. There are two main gendered characters, namely feminine and masculine individuals. These two characters contain characteristics that become individual traits, and forcing women with feminine characteristics to enter the masculine sphere is tantamount to exploiting them. This is not equality, which instead involves opening the widest possible opportunity so that both genders are given the choice to work and access their rights and obligations according to their optimal roles, without being discriminated against.

It is undeniable that there are differences in men and women's characteristics, but these cannot measure whether someone is good or bad at a job or activity. Each gender's uniqueness is not an indicator to judge which characteristics are better, nor which gender is better at work. Instead, feminine and masculine individuals are a complementary whole, and good arises as a result of the balance between the two [30]. Optimization of gender roles will be realized when a person is judged on their competence, rather than through gender stereotypes. A woman does a job not because of her gender, but because she is a competent human being. Ultimately, to achieve equality, we should not place the same burden on men and women, but present open opportunities. Equality is not equalizing men and women but equalizing the positions available to them. This means that a job should not be valued based on the level of difficulty or the material obtained, because the roles of both women and men have the same value and complement each other. The women's role in the domestic sector is equal to men's, and when women want to engage in the public sector, they should not be prevented, because women also need to actualize themselves, regardless of their feminine or masculine characteristics.

\section{Materials and Methods}

\subsection{Location of Study and Number of Samples}

The study was conducted in Parigi Moutong Regency from September to December 2019. The location determination was done purposively with the consideration that the study location had a number of women farmers who participated in the lowland rice farming. The number of lowland rice farming involved women farmers of 168 respondents, so the 
determination of the number of samples was done by the census.

\subsection{Analytical Framework}

The role of women farmers in the production of lowland rice was a discrete choice model, so the model used to analyze the role of women farmers is logistic or logit regression. The role of the women farmers is a dummy variable, equal to 1 if active and 0 if otherwise. This model has been used in many studies [31-35] to estimate the adoption of agricultural technology.

The logit model generally can be written as follows:

$$
P_{i}=E\left(Y=1 ; \mathrm{X}_{\mathrm{i}}\right)=\frac{1}{1+\mu^{-\left(\beta_{0}+\beta_{i} X_{i}\right)}}
$$

if $D_{i}=\beta_{0}+\beta_{i} X i$ then:

$$
P_{i}=\frac{1}{1+\mu^{-D_{i}}}=\frac{\mu^{D_{i}}}{1+\mu^{D_{i}}}
$$

Where $\mathrm{Pi}$ is the probability for the role of active women farmers, then the non-active one is (1-Pi) and $\mathrm{Xi}$ is the independent variable that affects it. Equation (2) represents the logistics distribution function, where:

$$
\left(1-P_{i}\right)=\frac{1}{1+\mu^{D_{i}}}
$$

Further:

$$
\frac{P_{i}}{1-P_{i}}=\frac{1+\mu^{D_{i}}}{1+\mu^{-D_{i}}}=\mu^{D_{i}}
$$

If equation (4) is in natural logarithms:

$$
\operatorname{Ln}\left(\frac{P_{i}}{1-P_{i}}\right)=D_{i}=\beta_{0}+\beta_{i} X_{i}+\mu
$$

Where Di is the observed response to the role of women farmers in lowland rice production. $\beta$ is the parameter and $\mu$ is the error term.

Multiple regression with the Cobb-Douglas production function model was used to analyze the effect of input and the role of women farmers on lowland rice yield, with the following model:

$$
Q=\alpha_{0} W_{1}^{\alpha_{1}} \cdot W_{2}^{\alpha_{2}} \ldots W_{i}^{\alpha_{i}} e^{\varepsilon}
$$

The completion of the function (6) was done by natural logarithm (ln) so that equation (6) becomes. $\mathrm{Q}=\alpha_{0}+\alpha_{1} W_{1}+\alpha_{2} W_{2}+\cdots+\alpha_{i} W_{i}+\varepsilon$

Where $\mathrm{Q}$ is the dependent variable, $\mathrm{W}$ is the independent variable, $\alpha$ is the parameter estimated by the ordinary least squares (OLS) method and $\varepsilon$ is the error term.

\subsection{Empirical Model}

The logit model was used to analyze the role of women farmers of lowland rice. The logit model in this study is as follows:

$D=\beta_{0}+\beta_{1} X_{1}+\beta_{2} X_{2}+\beta_{3} X_{3}+\beta_{4} X_{4}+\mu$

$\mathrm{D}=$ role of women farmers $(1=$ active and $0=$ otherwise), $\beta_{0}=$ intercept, $\beta_{1}-\beta_{4}=$ coefficient of the independent variables, $\mathrm{X}_{1}-\mathrm{X}_{4}=$ independent variables, $\mu=$ error term.

The independent variables are defined as follows:

$\mathrm{X}_{1}=$ age of women farmers

$\mathrm{X}_{2}=$ education of women farmers

$\mathrm{X}_{3}=$ number of dependents of women farmers

$\mathrm{X}_{4}=$ farming income of lowland rice of women farmers

Multiple Linear Regression with the CobbDouglas production function model was used to analyze the effect of input and the role of women farmers on lowland rice yield with the following model:

$\mathrm{Q}=\alpha_{\mathrm{O}}+\alpha_{1} \mathrm{~W}_{1}+\alpha_{2} \mathrm{~W}_{2}+\alpha_{3} \mathrm{~W}_{3}+\alpha_{4} \mathrm{~W}_{4}+\alpha_{5} \mathrm{D}+\varepsilon$

(9)

$\mathrm{Q}=$ lowland rice yield, $\alpha_{0}=$ intercept, $\alpha_{1}-\alpha_{4}=$ coefficient of the independent variables, $\mathrm{W}_{1}$ $\mathrm{W}_{4}=$ independent variables, $\varepsilon=$ error term. The independent variables are defined as follows: $\mathrm{W}_{1}=$ land area, $\mathrm{W}_{2}=$ urea, $\mathrm{W}_{3}=\mathrm{SP}-36, \mathrm{~W}_{4}=$ labor.

\section{Results and Discussion}

\subsection{The Location Descriptive and Study Variables}

Parigi Moutong Regency has an area of 6,231.85 Ha and a coastline of $\pm 472 \mathrm{Km}$. The geographical location of the Parigi Moutong Regency is $0.75^{\circ} \mathrm{NL}$ - $1^{\circ}$ SL and $120^{\circ}-121.5^{\circ}$ EL. Parigi Moutong Regency is at an altitude of $0-2900 \mathrm{~m}$ above sea level. The shape of the land surface in the Parigi Moutong Regency varies from the plains to the mountains with the following distribution [36]:

Flat $(0-8) \%=146,134 \mathrm{Ha}$,

Wavy $(8-15) \%=60,443 \mathrm{Ha}$,

Steep $(15-45) \%=142,186 \mathrm{Ha}$, and

Very steep $(>45) \%=1.97 \mathrm{Ha}$.

The description of the study variables is reported in Table 1.

Table 1 . The description of the study variables

\begin{tabular}{cccr}
\hline $\begin{array}{c}\text { Variabl } \\
\mathrm{e}\end{array}$ & Units & Mean & $\begin{array}{r}\text { Std. } \\
\text { deviation }\end{array}$ \\
\hline $\mathrm{D}$ & $\begin{array}{c}\text { Active }=1, \text { otherwise }= \\
0\end{array}$ & 0.32 & 0.47
\end{tabular}




$\begin{array}{lcrr}\mathrm{Q} & \text { ton/farm } & 5.25 & 3.91 \\ \mathrm{X}_{1} & \text { Number of years } & 43.45 & 9.15 \\ \mathrm{X}_{2} & \text { Likert scale } & 1.66 & 0.88 \\ \mathrm{X}_{3} & \text { number of people } & 2.93 & 1.25 \\ \mathrm{X}_{4} & \mathrm{IDR} / \text { farm } & 2,464,285.71 & 1,180,743.77 \\ \mathrm{~W}_{1} & \text { ha/farm } & 1.04 & 0.70 \\ \mathrm{~W}_{2} & \mathrm{~kg} / \text { farm } & 267.86 & 110.55 \\ \mathrm{~W}_{3} & \mathrm{~kg} / \text { farm } & 202.68 & 94.59 \\ \mathrm{~W}_{4} & \text { man-days/farm } & 123.18 & 52.39\end{array}$

The role of the women in lowland rice production was less than $50 \%$, meaning that most women farmers were less active in helping their husbands in the specific study area. Denkyirah et al [37] and Effendy et al [35] state that men had greater access to farming. The number of lowland rice yields in the study area averaged $5,250 \mathrm{~kg} / \mathrm{farm}$ of harvest dry grain, causing farmers' income to remain low at 2,464,285 IDR / farm per six months. The average age of a women farmers was 43 years; essentially, a still-productive age with more energy [38]. The level of education shows that most women farmers had only basic education, affecting the number of farmers able to adopt technology [39, 40]. The number of dependents in the farmers' family was three persons on average - this low number requires families to seek labor outside the family. Farmers' average land area of 1 ha could affect lowland rice production (still low). The use of fertilizer in production would also affect the production of lowland rice, as well as its income: the higher the production, the higher the income from lowland rice farming by assuming other factors were constant [41].

\subsection{Factors Affecting Women Farmers 4.2.1 Model Valuation}

The logit model valuation can be seen from the SPSS processed results in Table 2.

Table 2. Valuation of logit model

\begin{tabular}{lcc}
\hline \multicolumn{1}{c}{ Description } & Value & $\begin{array}{c}\text { Critical } \\
\text { value }\end{array}$ \\
\hline Omnibus test & 0.00 & $<0.05$ \\
Hosmer and Lemeshow Test (Chi-square) & 0.13 & $>0.05$ \\
Nagelkerke R Square & 0.41 & \\
\hline
\end{tabular}

The SPSS results show the probability value of the Omnibus test $0.001<0.05$, indicating a better regression model. The probability value of Hosmer and Lemeshow Test of $0.13>0.05$ means accept $\mathrm{H}_{0}$. This indicates that the logit model is suitable for further analysis, with a model accuracy of $41 \%$ at $\alpha$ $5 \%$.

\subsubsection{The Testing of Regression Coefficient}

The logit model was used to analyze the factors affecting the role of women farmers in lowland rice production. The results are presented in Table 3.

Table 3. Parameters estimation of the logit model regarding the role of women farmers

\begin{tabular}{ccccccc}
\hline Variable & B & S.E. & Wald & Df & \multicolumn{1}{c}{ Sig. } & $\operatorname{Exp(B)}$ \\
\hline $\mathrm{X}_{1}$ & 0.050 & 0.043 & 1.338 & 1 & 0.247 & 1.051 \\
$\mathrm{X}_{2}$ & 0.901 & 0.465 & 3.760 & 1 & $0.052^{*}$ & 2.462 \\
$\mathrm{X}_{3}$ & 0.012 & 0.273 & 0.002 & 1 & 0.965 & 1.012 \\
$\mathrm{X}_{4}$ & 0.000 & 0.000 & 7.885 & 1 & $0.005 * * *$ & 1.000 \\
Constant & -7.053 & 2.739 & 6.632 & 1 & $0.010^{* *}$ & 0.001
\end{tabular}

Note: $* * *$ significant at $1 \%$ level $(\mathrm{p}<0,01)$

$* *$ significant at $5 \%$ level $(\mathrm{p}<0,05)$

$*$ significant at $10 \%$ level $(\mathrm{p}<0,10)$

Table 3 shows how the education and income of lowland rice farming affected the production by women farmers. Education had a positive and significant effect on the role of women farmers. Exp (B) value of 2.462 , indicates that higher-educated women farmers would do activities in lowland rice production 2.462 times greater than those with less education, meaning that more educated women farmers would tend to help their husbands in producing lowland rice. The results are in accordance with the findings of Caleb and Ramatu [40] and Effendy et al [35] which state that education would affect farmers in making changes in farming. Farmers who were more highly educated had the motivation to increase their farming production.

The income of lowland rice farming had a positive and significant effect on the role of women farmers in lowland rice production. Exp (B) value of 1.00, indicates that women farmers who had a higher lowland rice farming income would do activities one time greater than those with lower income. This means that the income of lowland rice farming would increase the possibility of carrying out women farmers' activities in the production of lowland rice. High incomes could help farmers to buy inputs [42, 43] so that activities in production increased.

\subsection{Factors that Affected Production}

Factors the affected lowland rice production were analyzed using multiple linear regression of the Cobb-Douglas production function model as presented in Table 4.

Table 4. Estimation of study parameter

\begin{tabular}{lrrr}
\hline Variable & Coefficients & Std. error & Significant \\
\hline Intercept & 1.267 & & \\
$\mathrm{~W}_{1}$ & $0.695 * * *$ & 0.053 & 0.000 \\
$\mathrm{~W}_{2}$ & $0.317 * * *$ & 0.045 & 0.000 \\
$\mathrm{~W}_{3}$ & $0.386^{* * *}$ & 0.050 & 0.000
\end{tabular}




\begin{tabular}{lrrr}
$\mathrm{W}_{4}$ & $0.075^{*}$ & 0.044 & 0.092 \\
$\mathrm{D}$ & $0.529 * * *$ & 0.053 & 0.000 \\
Adjusted R Square & 0.906 & & \\
\hline
\end{tabular}

Note: $* * *$ significant at $1 \%$ level $(\mathrm{p}<0,01)$

$* *$ significant at 5\% level $(\mathrm{p}<0,05)$

* significant at $10 \%$ level $(\mathrm{p}<0,10)$

Table 4 shows that land area, urea fertilizer, SP-36 fertilizer, labor force, and the role of women farmers had a significant effect on the lowland rice yield. The land area had a positive and significant effect on the lowland rice yield at $\alpha 1 \%$, indicating that the addition of land areas could significantly increase lowland rice production. This finding shows that land area had a very important role in rice farming self-sufficiency. This result was supported by findings from Effendy [41], Effendy [44], and Zen [45] that land area had a role in increasing agricultural production. Besides the land area, urea and SP-36 fertilizers also had a positive and significant effect on the lowland rice yield at $\alpha 1 \%$. This shows that the use of fertilizer still played a role in increasing the lowland rice yield in the study area. This result was supported by the findings of $\mathrm{Li}$ et al [46] and Effendy [44] that fertilizer could increase agricultural production. Fertilizers could increase nutrients in the soil that are much needed by lowland rice plants.

Labor had a positive and significant effect on the lowland rice yield at $\alpha 10 \%$. This shows the addition of labor could increase the lowland rice yield. This result was supported by the findings of $\mathrm{Li}$, et al [46], Effendy [41], and Effendy et al [47] that labor could increase agricultural production. Sufficient and skilled labor could complete the work in the production of lowland rice effectively and efficiently, such as fertilizing, controlling pests and diseases, and post-harvest.

The role of women farmers had a positive and significant effect on the lowland rice yield at $\alpha$ $1 \%$. The women farmers had the second-highest role after land area in affecting the production of lowland rice, demonstrating the contribution of women farmers played an important role in increasing the lowland rice yield involving nurseries, dispelling bird attacks, and post-harvest work. This result was supported by the findings of Laven and Pyburn [10], White [11], Wijers [12], and Effendy et al [13]; overall, women farmers play an important role in agricultural production. Increasing human resources (women farmers) could be done by giving them innovation [48-50].

\section{Conclusion}

The role of women farmers in the production of lowland rice was affected by their education and farming income, with the effect on income being the most dominant. Land area, urea fertilizer, SP-36 fertilizer, labor, and the role of women farmers had a positive and significant effect on the lowland rice yield, but land area in conjunction with women farmers was greater. It was expected that farming households would optimize the use of women laborers as well as increasing resources through extension and training.

\section{Acknowledgments}

The authors would like to thank the Kemenristekdikti for providing support for this research.

\section{References:}

[1] Effendy, Changes of technical efficiency and total factor productivity of cocoa farming in Indonesia, Bulgarian Journal of Agricultural Science, Vol. 24, No. 4, 2018, pp. 566-573.

[2] M. Antara, Effendy, Allocation optimization of farmers' resources to achieve maximum income in Parigi Moutong Regency, Asian J. Sci. Res., Vol. 11, 2018, pp. 267-275.

[3] Sudarta, Peran Wanita Dalam Pembangunan Dalam Berwawasan Jender. Http://Ejournal.Unud.Ac.Id/Abstrak/Peranwani ta.Pdf, 2010.

[4] K.M.S. Sukesi, Hubungan Kerja Dan Dinamika Hubungan Gender Dalam Sistem Pengusahaan Tebu Rakyat. Lembaga Penerbitan Fakultas Pertanian Universitas Brawijaya. Malang, 2002.

[5] International Cooperative Alliance (ICA) Asia and Pacific, Resource guide for advanced training of cooperatives on entre- preneurship development of women and gender equality. Brus- sels: ICA, 2015.

[6] Worldbank, World development report 2012. Gender equality and development. Washington, DC.: Worldbank, 2012.

[7] C. Valdivia, Gender, livestock assets, resource management, and food security: Lessons from the SR-CRSP, Agriculture and Human Values, Vol. 18, 2001, pp. 27-39.

[8] E. Lecoutere, The impact of agricultural cooperatives on wom- en's empowerment: Evidence from Uganda, Journal of Cooperative Organization and Management, Vol. 5, 2017, pp. 14-27. 
[9] F. Duguid, N. Weber, Gender equality and women's empow- erment in co-operatives. Brussels: ICA, 2016.

[10] A. Laven, R. Pyburn, Facilitating gender inclusive agri- business, Knowledge Management for Development Journal, Vol. 11, No. 1, 2015, pp. 10-30.

[11] B. White, Changing childhoods: Javanese village children in three generations, Journal of Agrarian Change, Vol. 2012, 2016, pp. 8197. https://doi.org/10.1111/j.14710366.2011.00338.x

[12] G.D.M. Wijers, Inequality regimes in Indonesian dairy cooperatives: understanding institutional barriers to gender equality, Agriculture and Human Values, Vol. 36, 2019, pp. 167-181. https://doi.org/10.1007/s10460-018-09908-9

[13] Effendy, M.F. Pratama, R.A. Rauf, M. Antara, M. Basir-Cyio, Mahfudz, et al., Factors influencing the efficiency of cocoa farms: A study to increase income in rural Indonesia, PLoS ONE, Vol. 14, No. 4, 2019, pp. e0214569.

[14] C. Liu, L. Wang, A formative assessment of gender awareness and ability of staff based on the service programs of the All-China Women's Federation: The case of the "3861 My Home" program, Evaluation and Program Planning, Vol. 78, 2020, pp. 101732

[15] S.L. Bem, Gender Schema Theory: A cognitive Account of Sex Typing. Psychological Review, 1981.

[16] O.W. Johnson, J.Y. Han, K. Anne-Louise, S. Mortensend, M.Y. Aung, M. Boyland, B.P. Resurrección, Intersectionality and energy transitions: A review of gender, social equity and low-carbon energy, Energy Research \& Social Science, Vol. 70, 2020, pp. 101774.

[17] J.M. Platt, L.M. Bates, J. Jager, K.A. McLaughlin, K.M. Keyes, Changes in the depression gender gap from 1992 to 2014: Cohort effects and mediation by gendered social position, Social Science \& Medicine, Vol. 258, 2020, pp. 113088.

[18] O.S. Ewemooje, A.Y. Amoateng, E. Biney, Survey data on gender in relation to youth political discussion and involvement at a Public University in Ghana, Data in Brief, Vol. 31, 2020, pp.105796

[19] C. Ferrand, G. Martinent, N. Bailly, C. Giraudeau, K. Pothier, O. Aglia, Change of depressive symptoms in a French nine-year longitudinal study of aging: Gender differences and relationships between social support, health status and depressive symptoms, Archives of Gerontology and Geriatrics, Vol. 89, 2020, pp. 104059.
[20] M.A. Andersson, C.E. Harnois, Higher exposure, lower vulnerability? The curious case of education, gender discrimination, and Women's health, Social Science \& Medicine, Vol. 246, 2020, pp. 112780.

[21] R. Wang, G. Xu, Can child allowances improve fertility in a gender discrimination economy? Economic Modelling, Vol. 93, 2020, pp. 162-174.

[22] L.C. Ridgeway, Framed by Gender: How Gender Inequality Persist in the Modern World. New York: Oxford University Press, 2011.

[23] B. Anghel, N. Rodríguez-Planas, A. Sanz-deGaldeano, Is the math gender gap associated with gender equality? Only in low-income countries, Economics of Education Review, Vol. 79, 2020, pp. 102064.

[24] M. Kaffenberger, L. Pritchett, Aiming higher: Learning profiles and gender equality in 10 low- and middle-income countries, International Journal of Educational Development, Vol. 79, 2020, pp. 102272.

[25] A. Milner, A.J. Scovelle, B. Hewitt, H. Maheen, L. Ruppanner, T.L. King, Shifts in gender equality and suicide: A panel study of changes over time in 87 countries, Journal of Affective Disorders, Vol. 276, 2020, pp. 495-500.

[26] J. Browne, The Future of Gender. Cambridge: Cambridge University Press, 2007.

[27] G.R. Gupta, N. Oomman, C. Grown, K. Conn, S. Hawkes, Y.R. Shawar, et al., Gender equality and gender norms: framing the opportunities for health. The Lancet, Vol. 393, 2019, pp. 2550-2562.

[28] S. Belaounia, T. Tao, H. Zhao, Gender equality's impact on female directors' efficacy: A multicountry study, International Business Review, Vol. 29, No. 5, 2020, pp. 101737.

[29] M. Lansu, I. Bleijenbergh, Y. Benschop. Just talking? Middle managers negotiating problem ownership in gender equality interventions, Scandinavian Journal of Management, Vol. 36, 2020, pp. 101110.

[30] S. Reidl, S. Beranek, F. Holzinger, J. Streicher, Gender equality regimes and evaluation regimes in Europe and their implications for policy design and evaluation, Evaluation and Program Planning, Vol. 83, 2020, pp. 101860.

[31] G. Giannoccaro, J. Berbel, Farmers' stated responses towards the chemicals use under the CAP liberalization, Agric. Econ. - Czech, Vol. 60, No. 1, 2014, pp. 9-20.

[32] T. Alemu, Socio-economic and Institutional Factors Limiting Adoption of Wheat Row Planting in Selected Districts of Arsi Zone, Sci. Technol. Arts Res. J., Vol. 4, No. 1, 2015 , pp. 229-233. 
[33] T. Wade, L. Kurkalova, S. Secchi, Modeling Field-Level Conservation Tillage Adoption with Aggregate Choice Data, Journal of Agricultural and Resource Economics, Vol. 41, No. 2, 2016 , pp. 266-285.

[34] R. Ghimire, G.T. Green, K.P. Paudel, N.C. Poudyal, H.K. Cordel, Visitors' Preferences for Freshwater Amenity Characteristics: Implications from the U.S. Household Survey, Journal of Agricultural and Resource Economics, Vol. 42, No. 1, 2017 , pp. 90-113.

[35] Effendy, M. Antara, R.A. Rauf, D. Tangkesalu, Christoporus, et al., The Decision of Farmers do Fermentation to Increase the Quality of Cocoa Beans: A Case Study in Central Sulawesi Indonesia, Int. J Sup. Chain. Mgt., Vol. 8, No. 3, 2019 , pp. 790794.

[36] BPS, Kabupaten Parigi moutong Dalam Angka. Badan Pusat Statistik (BPS) Kabupaten Parigi mouton, 2018.

[37] E.K. Denkyirah, E.D. Okoffo, D.T. Adu, A.A. Aziz, A. Ofori, E.K. Denkyirah, Modeling Ghanaian cocoa farmers' decision to use pesticide and frequency of application: the case of Brong Ahafo Region, SpringerPlus, Vol. 5, 2016, pp.1113.

[38] K.W. Paxton, A.K. Mishra, S. Chintawar, R.K. Roberts, J.A. Larson, B.C. English, ... S.W. Martin, Intensity of Precision Agriculture Technology Adoption by Cotton Producers, Agricultural and Resource Economics Review, Vol. 40, No. 1, 2011, pp. 133-144.

[39] A.A. Enete, E.M. Igbokwe, Cassava market participation decisions of producing households in Africa, Tropicultura, Vol. 27, No. 3, 2009, pp. 129-136.

[40] D. Caleb, A. Ramatu, Factors influencing participation in rice development projects: the case of smallholder rice farmers in Northern Ghana, Int J Dev Econ Sustain, Vol. 1, No. 2, 2013, pp. 13-27.

[41] Effendy, Efisiensi Faktor Produksi dan Pendapatan Padi Sawah di Desa Masani Kecamatan Poso Pesisir Kabupaten Poso, $J$. Agroland, Vol. 17, No. 3, 2010, pp. 233 240.

[42] I. Jan, Socio-Economic Determinants of Farmers' Adoption of Rainwater Harvesting Systems in Semi-Arid Regions of Pakistan, $J$. Agr. Sci. Tech., Vol. 22, No. 2, 2020, pp. 377387.

[43] G.M.A. Nonvide, Identification of Factors Affecting Adoption of Improved Rice Varieties among Smallholder Farmers in the
Municipality of Malanville, Benin, J. Agr. Sci. Tech, Vol. 22, No. 2, 2020, pp. 305-316.

[44] Effendy, Factors affecting variation of total factor productivity in cocoa farming in the Central Sulawesi, Indonesia, AJCS., Vol. 12, No. 4, 2018, pp. 655-660. doi: 10.21475/ajcs.18.12.04.pne1025

[45] I. Zen, M. Antara, R.A. Rauf, Comparative Analysis of Wetland Rice Farming System of Ciliwung and Cigeulis Varieties in Tatakalai Village of North Tinangkung Sub District Banggai Island Regency, J. Agroland, Vol. 24, No. 1, 2017, pp. 1 - 9 .

[46] X. Li, Y. Luo, Q. Gao, S. Dong, X. Yang, Farm Production Growth in the Upper and Middle Parts of the Yellow River Basin, China, During 1980-1 999, Agricultural Sciences in China, Vol. 7, No. 3, 2008, pp. 344-355.

[47] Effendy, N. Hanani, B. Setiawan, A.W. Muhaimin, Characteristics of Farmers and Technical Efficiency in Cocoa Farming at Sigi Regency - Indonesia with Approach Stochastic Frontier Production Function, Journal of Economics and Sustainable Development, Vol. 4, No. 14, 2013, pp. 154-160.

[48] K.A. Theophilus, S.M. Paul, The impact of savings groups on female agency: insights from village savings and loans associations in Northern Ghana, Asian Journal of Agriculture and Rural Development, Vol. 9, No. 2, 2019, pp. 133-146.

[49] R. Prasetyanti, H.R. Susilatun, Innovating Rural: A Comparative Analysis of Community-Driven Rural Innovation in North Sumatera and Yogyakarta, Indonesia, International Journal of Innovation, Creativity and Change, Vol. 11, No. 2, 2020, pp. 306324.

[50] S. Singh, Spatio-temporal changes in the patterns of male and female agricultural labour in Punjab: A geographical analysis, Asian Journal of Agriculture and Rural Development, Vol. 10, No. 1, 2020 , pp. 183193.

\section{Creative Commons Attribution License 4.0 (Attribution 4.0 International , CC BY 4.0)}

This article is published under the terms of the Creative Commons Attribution License 4.0 https://creativecommons.org/licenses/by/4.0/deed.en US 